\title{
The Impact of Adopting Corporate Social Responsibility on Corporate Financial Performance: Evidence From Italian Listed Companies
}

\author{
Giovanni Landi \\ Research Fellow in Management \\ Department of Economics, Management and Institutions \\ University of Naples 'Federico II', Via Cinthia - 80126 Naples, Italy
}

Valerio Rapone (Corresponding author)

Ph.D in Management

Department of Economics, Management and Institutions

University of Naples 'Federico II', Via Cinthia - 80126 Naples, Italy

Tel: 39-081-675-303 E-mail: valerio.rapone@ unina.it

Received: October 3, 2018 Accepted: November 20, 2018 Published: November 26, 2018

doi:10.5296/ijafr.v8i4.13734

URL: https://doi.org/10.5296/ijafr.v8i4.13734

\begin{abstract}
This paper aims to analyse whether social rating can impact on financial performance of major Italian companies listed on the stock exchange and, subsequently, whether the Italian stock market has proved awareness of social and environmental issues.

The study will highlight how companies included in the Italian FTSE MIB index have reacted to the Subprime Mortgage and Sovereign Debt crises, opting for socially responsible investments. The analysis describes the stock exchange trend of the FTSE MIB index companies, considering the ethical rating assigned to them by Standard Ethics on a yearly basis, over a period ranging from 2007 to 2013.

The results of the Panel Data analysis conducted on the chosen sample seek to explain whether an ethical rating is a discriminating variable for an investor, analysing the existence
\end{abstract}


of a significant relationship between socially responsible investments of a listed company and its stock market performance.

Keywords: Socially responsible investment, Corporate social performance, Ethical finance, Corporate financial performance, Ethical rating, Corporate social responsibility

\section{Introduction}

In recent years increasing interest has been brought to the impact of Corporate Social Responsibility (CSR) on economic and financial performance of listed companies. Many economists have abandoned the axioms of classical economics as self-regulation and market efficiency (Fama, 1970, 1976; Sen, 2002) recognizing the corrective function that Corporate Social Responsibility can have in a market less sustainable and characterized by strong information asymmetries (Moskowitz, 1972, 1975). The growing awareness developed by top managers towards the different categories of stakeholders has produced a positive impact on medium and long-term profitability of the managed entities. Such profitability is attributable to diverse factors whose nature and scope is not always grasped by the stock exchange market, namely variables that are not typical of technical or fundamental analysis. Hence, the myopia of investors incapable to detect such variables has led some rating agencies to specialise in the formulation of indicators that express the degree of social and environmental responsibility of listed company's decisions.

The criteria used to assess this aspect are based on three types of observations that take into account the impact that every corporate decision produces on both the environment and the community in which the company acts.

In the scoring process of a social rating, this paradigm is better known as Environmental, Social and Governance evaluation (ESG). Business strategies based on stakeholder view, led companies to prepare further account statements that, in addition to the economic budget, would provide a clear and truthful vision of a sustainable entity: e.g. the redaction of social and environmental statements and the preparation of an ethical code primarily for internal stakeholders.

\section{Research Question}

This paper focuses on the Italian stock market, carrying out the importance of including further aspects in the stock evaluation, such as an ethical rating.

Italy has shown a high growth rate of Socially Responsible Investment (SRI) by companies. Indeed, between 2011 and 2013, sustainable and socially responsible investments recorded a total amount of $2.000 \mathrm{Mln} €\left(\mathrm{VI}^{\circ}\right.$ Sustainable and Socially Responsible Investments Analysis -EUROSIF 2014). On this ground, the aim of this work is to analyse whether the level of sustainability of an Italian listed company may have an impact on its financial performance and whether investors consider an ethical rating a viable choice driver in the screening of their investment portfolio. By doing so, this study seeks to understand whether economic actors that allocates their monetary resources on the major Italian securities, combine financial investors' objectives with their concerns about ESG issues. 
An additional purpose is to highlight whether companies under investigation that manage environmental and social risks developing long-term sustainable growth strategies, can consider ESG factors value drivers for improving their stock market performance. In order to verify such hypothesis, a descriptive analysis on FTSE MIB index was performed to assess whether the ethical side of the Italian market has prevailed over the unethical ones in the worst phase of the Subprime Mortgage and the Sovereign Debt crises.

The goal is to identify a systemic trend that reflects the sustainability of the Italian industrial sectors over a period ranging from 2007 to 2013, as well as to determine the incidence of the ethical companies basket compared to the 40 major stocks listed on the Italian stock exchange.

\section{Literature Review}

In order to provide a comprehensive definition of ethical investor and social responsible investment, diverse perspectives need to be considered. The first category to be observed is the subject-investor, whose investment decisions comprise both financial-economic criteria (such as risk/earning), as well as other factors based on socio-environmental and ethical principles (Gangi, 2011; Signori, 2006). Hence, equal attention should be paid to the decisional processes implemented to attain and maintain a certain investment profit margin. To this end, several criteria should be taken into account, which range from ethical limits and purposes, to social and/or environmental issues and to the merely financial selection principles (Cowton, 1999). Therefore, the ethical investor is not only concerned about the expected financial returns and its related risk, but also about the impact that a certain investment can engender at the social and environmental level. This triggers a double implication: on the one hand, the ethical investor should be thoroughly informed and aware of the elements from which value (in terms of profitability) stems, on the other hand the multiple factors involved in the decisional process range from personal values to social evaluations and economic factors (Michelson et al., 2004). A firm decides to act "responsibly" in order to comply with environmental, social and financial issues stemming from both its internal "community", and the external environment in which it is embedded and for which it is engaged in the process of value creation. Such a view considers the firm as an open socio-economic system (Sciarelli, 2001) according to which the respect of the CSR can lead to benefits for both categories of actors.

The stakeholder theory provides a valid tool for a reliable interpretation of social responsible investment choices (Freeman 1984; Hannan, Freeman 1993; Donaldson et al. 1995, 1999, Post et al. 2002) since it broadens the set of subjects involved in, or influenced by, the firm's choices. Such a theoretical approach attempts to combine the economic and financial logic with business ethics premises in the framework of the decisional process occurring in the detection and evaluation of socially responsible investments. Thus, the stakeholder value paradigm reveals to be helpful to enrich the number of potential investors since the different stakeholder can be interested in investing either in human capital or in the social and environmental one (Gangi, 2011). 


\section{Mll Macrothink}

International Journal of Accounting and Financial Reporting ISSN 2162-3082 2018, Vol. 8, No. 4

Literature across decades has broadly addressed the linkages between Corporate Social Performance (CSP) and Corporate Financial Performance (CFP) in terms of whether and to what extent the social performance might affect financial performance (Preston and O'Bannon, 1997; Margolis and Walsh, 2003; Hunter and Schmidt, 2004; Allouche and Laroche, 2005). However, the findings achieved in both earlier studies and in more recent ones have proved controversial (Barnett and Salomon, 2012). Some of them have shown a negative relationship (Vance, 1975, Wright and Ferris, 1997), some others provide evidence of a weak (Cochran and Wood, 1984) or not significant correlation (Alexander and Buchholz, 1984; Patten, 1991; McWilliams and Siegel, 2000), whereas several authors found grounds for a positive linkage (Moskowitz, 1972; Bowman and Haire, 1975; Preston, 1978; Sturdivant and Ginter, 1977; Ingram, 1978; Anderson and Frankle, 1980; Orlitzky, Schmidt and Rynes, 2003). In general terms, every analysis should be verified taking into account the specific sector and the dimensions of the considered company but, as some have noticed (Margolis and Walsh 2003), this distinction has not always been performed. This leads to a research "bias", according to which finance researchers are keener on stressing no positive correlation, whereas academics sensitive to CSR issues tend to find evidence of a positive relationship between CSP and CFP (Griffin and Mahon, 1997). Academics seem to disagree regarding other firms 'responsibilities besides maximising shareholders profits (Flammer, 2015 and Wang et al., 2015). Thus, supporters of a positive CSP-CFP relationship point out that a firm deploying a "socially responsible" strategy does not necessarily imply a profits crunch due to CSR corporate policies. They state that a better CFP as a consequence of a good CSP is generally related to slack resources theory and that an information overload about ethical and moral issues can increase consumers' brand loyalty and their buying willingness (Schuler and Cording, 2006). Hence, companies leverage on CSR to benefit from high sales perspective. Robinson et al. (2011) show a significant improvement in market share of socially responsible firms belonging to the Dow Jones Sustainability Index. However, there could be a non-linear relationship, given that a firm financially wealthy can improve with a growing CSP up to CSR commitment and related expenses do not overcome a limit, implying a reverse U-shaped relationship (Barnea and Rubin, 2010). In addition, Lankoski (2008) shows an inverted-U relationship between CSR management and financial performance, considering that the marginal costs of CSR activities decrease the marginal revenues. Barnett and Salomon (2012) carried out a study which validates the U-shaped relationship between CSP and CFP, because of CSR requires capital-intensive investments which are not able to earn great returns. Scholtens (2008a) has been employing a different pattern for measuring social performance, highlighting emprically that banks'CSP improved significantly their CFP between 2000 and 2005. Recently, Nollet et al. (2016) demonstrates a positive association between firms'CSP and CFP, posing a cap after which CSR investments should lower.

\section{Research Method (Note 1)}

The aim of the present work is to investigate the relationship between corporate social responsibility (CSR) and corporate financial performance (CFP) of Italian stock market, using panel data for 38 listed firms from 2007 to 2013. 
At the present time, the issue is of great interest since the role of CSR is growing as academics and practitioners explore its impact on corporate performance on different dimensions. This timeline reflects the period of deep global and national crisis whose effects are still on-going. Events such as the American crisis of subprime mortgages and the Italian sovereign debt have sensitized the behaviour of Italian companies towards ethical and social issues and consequently changed the investment choices of market players.

In fact, a recent survey conducted by Grant Thornton International Ltd. (Note 2) reveals that $24 \%$ of Italian companies publish information on corporate social responsibility and sustainability, and integrate them into the budget (20\%) and in specific documents (4\%). The number of Italian companies that publish a social balance sheet has risen from 15\% in 2011 to the current $24 \%$. It is therefore important to understand how, under these relevant changes, the Italian stock market evaluates the social corporate performance.

We have tested the following hypothesis:

HP: CSR has a positive correlation with the financial performance of the listed Italian companies.

Our study examines whether the ethical rating assigned to the companies listed on the FTSE MIB (Financial Times Stock Exchange Milano Indice di Borsa) by the Standard Ethics rating agency, affects the financial results of the considered companies.

The analysis starts with the identification of the sample, composed of the companies in the index FTSE MIB in 2013 and whose quotations, in the considered timeline, are published in leading financial platforms. These companies have been classified as business ethics and unethical according to policies adopted by the agency Standard Ethics. Subsequently, it was necessary to identify the variables of economic, financial and market dimensions to analyse the correlations between social and financial performance. In order to test the above-mentioned relationship, we applied the panel data statistical model.

\subsection{The Dataset}

The dataset was built starting from the 40 firms FTSE MIB index in 2013, the main benchmark index of the Italian stock markets. This index, which captures about $80 \%$ of the domestic market capitalization, is composed of leading companies and high liquidity across ICB sectors in Italy. According to the definition provided by the Italian Stock Exchange Market, the FTSE MIB Index "measures the performance of 40 Italian equities and seeks to replicate the broad sector weights of the Italian stock market. The Index is derived from the universe of stocks trading on the main market of the Italian Stock Exchange (BIt)" (Note 3).

Each stock is analysed for size and liquidity, and the overall Index has appropriate sector representation.

The FTSE MIB Index is weighted by market capitalisation after the adjustment of constituents for the total amount of shares available for trading, namely the float. Therefore, once the companies in the sample have been identified, it was necessary to perform a subsequent reworking of the same, to identify companies whose quotations are public and 
available on the well-known financial platforms. For this reason, from the reference sample were excluded firms as Lottomatica and Fiat Industrial, whose quotations are not published. Therefore, the number of firms included in the analysis has downed to 38 . The ethical ratings associated with each of the firm in the panel were provided, by Standard Ethics' press releases. This sustainability rating Agency has been chosen since it is the first European rating agency focused on social responsibility, environmental and corporate governance, which is solicited, standard and independent at the same time. Standard Ethics differs from other companies and rating agencies because it considers as a reliable reference only the interpretations provided by the EU, the OECD and the UN.

Our choice was made after analysing the main indexes of responsibility including the Dow Jones Sustainability Index and the FTSE4Good.

According to the normative and/or institutional framework adopted, Standard Ethics was revealed to be a more objective indicator, thus suitable to evaluate performance of a financial nature. Companies have been classified according to rating grades assigned in the last seven years. The scale of ratings from Standard Ethics adopted on the basis of which were classified companies includes nine categories symbolized by the letter "E" of "ETHICS" and "ETHOS" (EEE, EEE-, + EE, EE, EE, E+, E, E-, SUSPEND or, in case that the company deviates significantly from the ethical principles of the agency). Starting from these categories it was possible to divide the sample into two subgroups, ethical and unethical, including in the first group all firms with levels (EEE, EEE-, + EE, EE, EE) and second levels (E-, E +, E, E-, or SUSP PEND) (Tomasi and Russo, 2012).

The analysis was first conducted at the general level, dividing the companies into two categories and then performance of each subgroup was examined according to the specific level of rating assigned.

It is important to specify that the composition of the groups during the reporting period can change according to two factors: the annual review of the ratings from Standard Ethics and the review of the FTSE MIB by the Italian Stock Exchange.

As to the first factor, the publication of the sustainability report updates the previous version and changes its judgment and the classification of the individual company. As to the second factor, the Italian Stock Exchange checks to see if the index components best represent the Italian market.

In fact, when a company leaves the reference basket, in the following period will not receive a rating from the agency. Simultaneously, companies that take over in place of the outgoing will receive the ratings only in the following period.

In addition, the composition of the group may change because of an urgent update of the rating by the Standard and Ethics in the event of extraordinary operations on companies under observation.

In fact, the rating agency usually tries to avoid changes during the year, except for special cases where it is possible to occur a downgrading or upgrading company following events of 
significant magnitude. The extraordinary transactions, such as delisting, mergers or acquisitions, may result in the temporary suspension of listing from the index and its exclusion. Our study is independent from these possible variations, because one of the basic assumptions of the statistical model used is the permanent presence of the same sample units to various years of analysis. Appendix 1 shows the reference sample, with the relative ratings assigned.

In relation to corporate social performance, we have identified some key variables: the dependent variable, focus on multiple market price earning (PE), or the ratio between the current price of a share at the time of the calculation of the index and the expected return for each share. This ratio is used to evaluate the quotes of action even in the due limits and has been widely adopted since earlier studies for this sort of analysis (Bragdon and Marlin, 1972; Bowman and Haire, 1975; Heinze, 1976; Preston 1978; Spicer, 1978). The PE also expresses the necessary time needed to make profits equal to the share price. Data were extracted from the database of Borsa Italiana, Morningstar portal and Yahoo Finance (Note 4). In order to fill random data blanks referring to the missing PE ratio, some revisions had to be performed by using the Earning per Share index and the average monthly quotation of its securities. The independent variables identified are based on operating, economic and financial dimensions. These variables are: profitability ratios ROE (return on equity) and ROA (return on assets), EBITDA (earnings before interest, tax, depreciation and amortization) or operating income, the financial leverage (defined as total assets divided by total shareholders' equity).

\subsection{The Methodology}

The study is divided into two sections. In the first section we comment the descriptive statistics as the trend of the ratings of the firms from 2007 to 2013 and the econometric analysis. In this way, it is possible to check whether Italian companies have taken ethical actions and have changed their rating level over the years. In the second section we have performed the statistical analysis through the model panel data to check the relationship between social and financial performance.

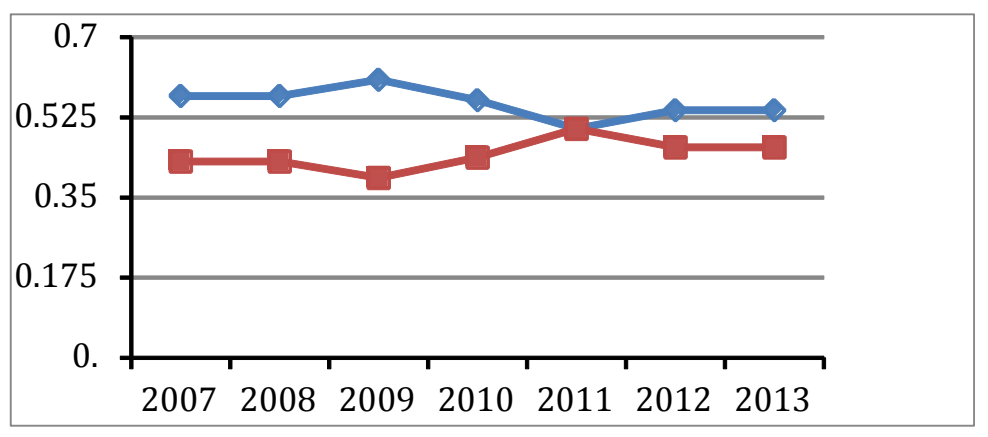

Figure 1. Trend of ethical and unethical group (\% of total) from 2007 to 2013

As the graphs show, the incidence of ethical group (blue line) is steadily higher than the related unethical group (red line) in the sample over the timeline (the highest point is reached in 2009: 0,6071 ethical VS 0,3928 unethical). 

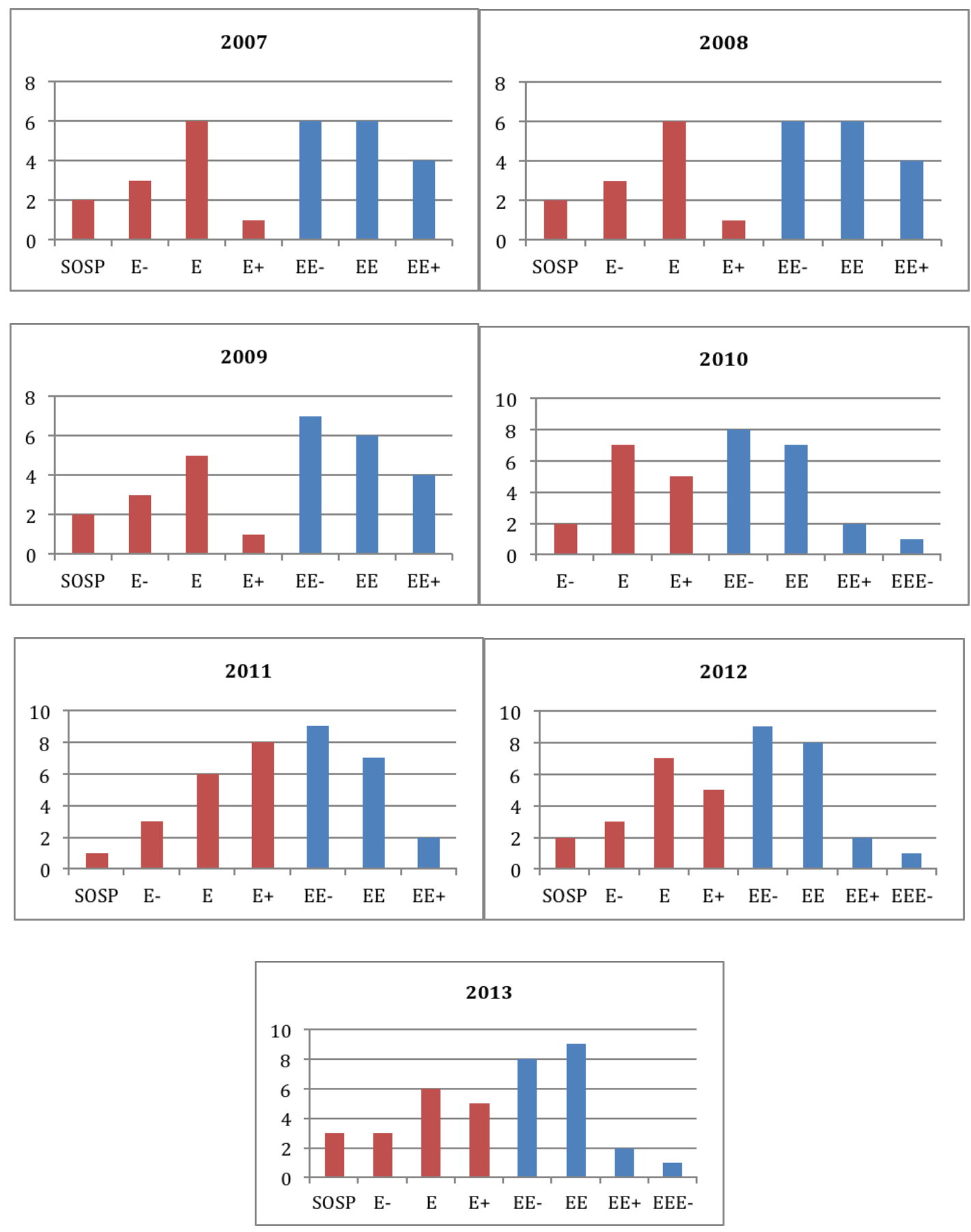

Figures 2-7. Frequency of groups considered for level of rating from 2007 to 2013

The ethical group with blue slash increases over years, from 16 units in 2007 to 20 units in 2013 (16-2007, 16-2008, 17-2009, 18-2010, 18-2011, 20-2012, 20-2013). This shows that in recent years the companies have increased their level of rating, thanks continuous investment in ESG. Companies have sensitized their behaviour, addressing some of the profits to the social and ethical costs. However, the unethical group is stable over time, going from 15 units in 2007 to 17 units in 2013.

For ethical group is known as the two predominant subgroups are those with rating levels EE- 
and EE, with a rating level defined in the sufficiency (the absence of level EEE is due to the fact that none of the companies of the panel have fully complied with the requirements needed for the highest rating score). While the sample unethical predominant subgroup E, with rating levels insufficient.

\subsection{The Descriptive Statistics}

Table 1. Descriptive statistics analysis

\begin{tabular}{llllll}
\hline Variable & Obs & Mean & Std. Dev & Min & Max \\
\hline P/E & 266 & 33.544 & 220.573 & -140.667 & 3333.3 \\
Rating & 266 & 3.87217 & 2.175033 & 0 & 8 \\
Ebitda & 266 & 20.911 & 30.717 & -199.98 & 148.29 \\
Roe & 266 & 10.737 & 14.794 & -40.08 & 102.83 \\
Roa & 266 & 3.626 & 5.056 & -10.28 & 23.29 \\
Fin.Lev. & 266 & 7.493 & 16.073 & 0 & 244.79 \\
Beta & 266 & 0.793 & 0.6463 & -0.95 & 5.367 \\
\hline
\end{tabular}

Table 2. Covariance and correlation matrix

\begin{tabular}{lllllll}
\hline Variable & Rating & Ebitda & Roe & Roa & Fin.Lev. & Beta \\
\hline Rating & 1 & & & & \\
Ebitda & 0.0309 & 1 & & & \\
Roe & -0.2427 & 0.3001 & 1 & & \\
Roa & -0.2306 & 0.1673 & 0.7076 & 1 & \\
Fin.Lev. & 0.0071 & -0.1586 & -0.1472 & -0.2045 & 1 & \\
Beta & 0.2006 & -0.0517 & -0.2244 & -0.2563 & 0.112 & 1 \\
\hline
\end{tabular}

Tables 1 and 2 compare the characteristics of descriptive statistics of variables. As shown by the results below, we can identify the PE as the variable characterized by a high volatility 


\section{Mll Macrothink}

International Journal of Accounting and Financial Reporting

ISSN 2162-3082

2018, Vol. 8, No. 4

level. For this reason we used the variable above as dependent variable of the model to analyse which among variables have a significant impact on its trend (D' Ambra L., 2004). Moreover even if the ethical basket is staidly composed by superior number of companies, the Italian stock market is on average unethical. Table 4 shows the correlations between independent variables. As we can see the variables with a strong positive correlation are Roe, Roa and Ebitda. The variable Rating reflects the idiosyncratic risk according to standard ethics issues and has a positive correlation with the regressing beta, which represents the systematic risk of each company under investigation. On our dataset we applied Panel Data Model (D’ Ambra L., 2000; Gelman A. and Hill J., 2007; Friedman A. D., 2009).

The main benefit of this model is that it allows to answer questions that we could not answer otherwise when using a sample cross-section or time series and to take into account the heterogeneity of the individuals of the sample. Before applying the model, it was necessary to determine whether it is applicable to a panel structure characterised by either fixed effects or random effects. The test of the hypothesis of no correlation between the explanatory variables and the individual effects is also a test on the reliability of the estimator RE. The test that we have used for this purpose is the well-known Hausman test (Dhrymes, P. J., 1994; Greene, W. H., 2000). This test allows us to verify whether or not the assumptions of the model is applicable, and indicates whether to apply the fixed effects model or random. The output shows a value of 0.1662 . We must reject the hypothesis $\mathrm{H}^{0}$ (pvalue < 0.05 ) and accept the hypothesis $\mathrm{H}^{1}$ of the test. The random effects model is not applicable. Therefore we have to use the fixed effects model. The test results are summarized in the following table:

Table 3. Hausman Test Results

Test $\left(\mathrm{H}^{0}\right)$ : difference in coefficients is not systematic

$$
\mathrm{Chi}^{2}(6)=(\mathrm{b}-\mathrm{B})^{\prime}\left[\left(\mathrm{V} \_\mathrm{b}-\mathrm{V} \_\mathrm{B}\right)^{\wedge}(-1)\right](\mathrm{b}-\mathrm{B})=9.13
$$

Prob. $>\mathrm{Chi}^{2}=0.1662$

Since the normality test analysis has not been sufficiently verified and the variable transformation adjustment has not been successful, the obtained results must be considered carefully and need additional verifications. Statistical panel data analysis highlights some important considerations.

The output of the model can be summarised as follows: 


\section{Mll Macrothink \\ International Journal of Accounting and Financial Reporting \\ ISSN 2162-3082 \\ 2018, Vol. 8, No. 4}

Table 4. Panel data analysis over FTSE MIB index from 2007 to 2013

\begin{tabular}{|c|c|c|c|c|c|c|}
\hline $\mathrm{PE}$ & Coeff. & Std. Error & $\mathrm{t}$ & $\mathrm{P}>|\mathrm{t}|$ & \multicolumn{2}{|c|}{ [95\% Conf.Int] } \\
\hline Rating & -1.4135 & 4.7310 & -0.3000 & 0.7650 & -10.7370 & 7.9099 \\
\hline Ebitda & 0.6700 & 0.2701 & 2.4800 & 0.0140 & 0.1378 & 1.2023 \\
\hline Roe & 0.4307 & 0.8738 & 0.4900 & 0.6230 & -1.2914 & 2.1527 \\
\hline Roa & -1.6246 & 3.1589 & -0.5100 & 0.6080 & -7.8499 & 4.6007 \\
\hline Fin.Lev. & 13.5916 & 0.4606 & 29.5100 & 0.0000 & 12.6838 & 14.4994 \\
\hline Beta & -4.0597 & 11.7594 & -0.3500 & 0.7300 & -27.2340 & 19.1145 \\
\hline _cons & -72.3512 & 22.0537 & -3.2800 & 0.0010 & -115.81 & -28.89 \\
\hline $\begin{array}{l}\text { Obs. } \\
\text { number }\end{array}$ & 266 & $\begin{array}{l}\text { R-sq: within } \\
=0.7971\end{array}$ & $\begin{array}{l}\text { Obs. } \quad \text { Per } \\
\text { group: } \min =7\end{array}$ & sigma_u & $=$ & 76 \\
\hline $\begin{array}{l}\text { Group } \\
\text { number }\end{array}$ & 38 & $\begin{array}{l}\text { between= } \\
0.5859\end{array}$ & $\operatorname{avg}=7.0$ & sigma_e & $=$ & 101 \\
\hline $\begin{array}{l}\text { Group } \\
\text { variable }\end{array}$ & Firms & $\begin{array}{l}\text { overall= } \\
0.7261\end{array}$ & $\max =7$ & rho & $=$ & 0.36 \\
\hline Prob. $>\mathrm{F}$ & 0.0000 & $\begin{array}{l}F(6.222)=14 \\
5.33\end{array}$ & $\begin{array}{l}\operatorname{corr}\left(\mathrm{u} \_\mathrm{i} \mathrm{Xb}\right)= \\
-0.03852\end{array}$ & $\begin{array}{l}\text { test that all } \\
u_{-} \mathrm{i}=0\end{array}$ & $\mathrm{~F}(37.222)$ & 2.68 \\
\hline
\end{tabular}

As the table shows, the total amount of analysed observations is 266. Our applied analysis is statistically significant, as the Prob $(\mathrm{F})$ is close to zero, while the index $\mathrm{R}^{2}$ is equal to $72 \%$. The result shows that the significant variables with a p-value less than 0.05 are Ebitda and Financial Leverage. These variables have coefficients equal to 0.6700 and 13,5916 . We can comment that companies with high financial performance are those with a higher operating profit and with a high rate of financial leverage. The variable of interest, Rating of Ethics is not statistically significant. Moreover, this variable has a negative coefficient equal to -1.4135. This means that the Italian market and consequently financial performance of the stocks of FTSE MIB, do not consider corporate social responsibility as a key variable in their investment choices. 


\section{Findings and Discussion}

Basing on our results, the Italian investors' market does not seem to be mature on CSR issue, hence from a short-term perspective investors do not appear promptly reactive to an improvement in the CSP of our firms' sample. Therefore, the variables which affect CFP remain those typical of fundamental analysis. This in turn could be related to the inefficient promotion of social ratings that companies receive, in order to make investors more conscious about the perceived risk where they are addressing their capitals, although entities attempt to reduce information asymmetry through CSR disclosure. The reason underlying the low financial performance of outstanding responsible shares on Italian stock exchange could be related to the lack of a reliable corporate strategy in social impact disclosure as well as CSR commitment, both meant to stimulate in a short timeframe a well-performing capital fund-raising on financial market and as a consequence a better CFP.

\section{Conclusion}

According to the results obtained to date, the incidence of the ethical rating on the financial performance of companies listed on the Italian stock market (see table IV) does not have a sufficient significance to justify the fluctuations of the PE proxy used to measure the stock exchange trends considered in our analysis. Moreover, any improvement observed in the ethical rating level of the chosen companies does not match with a comparable variation of the related stock market performance. In fact, the regression coefficient expressing such a relation was revealed to be negative.

Notwithstanding the fact that the selected basket of socially responsible companies has prevailed in comparison to the non-ethical basket along the observation timeline, the valuation of the total average level of sustainability of the Italian stock market sets on an extremely low rating level, according to the evaluation criteria adopted by the Standard Ethics agency.

The study has provided evidence of a scanty sensibility of the Italian stock exchange market towards an ethical evaluation of stocks to invest in. Even though Italian companies have allocated a substantial part of their capital to socially responsible investments, the market is not yet able to acknowledge this phenomenon as a pivotal aspect of investment choices. The emerging scenario shows that Italian Management trusts and investment funds do not invest in building SRI products and the SRI finance is a concept more widespread within international markets. The described outcomes put into light a breaking point between supply and demand, which could be derived from the lack of a sufficient amount of information helpful to evaluate - and eventually opt for- a socially responsible investment.

The limits of the present analysis concern the choice of the set of variables able to express the ethical level of a listed stock because the sole ethical rating is not able to explain the observed financial performances by itself.

Furthermore, to make the analysis more detailed, this study needs to take into account other unobserved variables impacting on financial performance of listed companies under investigation. In other words price earnings ratios include also the risks related to some 
macroeconomic variables such as country risk premium, national average tax rate, national R\&D investments, and so on. Reasonably the stock exchange market is opened to foreign investors, thus their forecasts are based also on economic, political and social stability typical of the country where they invest.

A further application emerging from the study could be to shift the focus from the earning variables internal to the firm to the different items of expenditure typical of a socially responsible firm policy. Thus, it could be possible to highlight the amount of value created in socially virtuous companies that the stock exchange market is not able to detect.

\section{References}

Alexander, G. J., \& Buchholz, R. A. (1978). Corporate Social Responsibility and Stock market Performance. Academy of Management Journal, 21(3), 479-486.

Allouche, J., \& Laroche, P. (2005). A meta-analytical investigation of the relationship between corporate social and financial performance. Revue de Gestion des Ressources Humaines, 57, 18-41.

Anderson, J. C., \& Frankle, A. W. (1980), Voluntary social reposting: An iso-beta portfolio analysis. The Accounting Review, 55(3), 467-479.

Barnea, A., \& Rubin, A. (2010). Corporate social responsibility as a conflict between shareholders. J Bus Ethics, 97, 71-86.

Barnett, M. L., \& Salomon, R. M. (2012). Does it pay to be really good? Addressing the shape of the relationship between social and financial performance. Strategic Management Journal, 33(11), 1304-1320.

Bowman, E. H., \& Haire, M. A. (1975). A strategic posture toward corporate social responsibility. California Management Review, 18(2), 49-58.

Bragdon, J. H., \& Marlin, J. A. (1972). Is pollution profitable?. Risk Management, 19(4), 9-18.

Cochran, P. L., \& Wood, R. A. (1984). Corporate Social Responsibility and Financial Performance. Academy of Management Journal, 27(1), 42-56.

Commissione delle comunità europee, libro verde. (2001). Promuovere un quadro europeo per la responsabilità sociale dell'impresa.

Cowton, C. (1999). Accounting and financial ethics: from margin to mainstream?. Business Ethics: A European Review, 8(2), 99-107.

D’Ambra, L. (2000). Lezioni di inferenza statistica. RCE multimedia.

D’ Ambra, L. (2004). Appunti di statistica descrittiva. RCE multimedia.

Dhrymes, P. J. (1994). Specification tests in simultaneous equations systems. Journal of Econometrics, 45-76. 


\section{Ill Macrothink}

International Journal of Accounting and Financial Reporting

ISSN 2162-3082

2018, Vol. 8, No. 4

Donaldson, T., \& Dunfee, T. W. (1999). Ties that bind: A social contracts approach to business ethics. Boston, MA: Harvard Business School Press.

Donaldson, T., \& Preston, L. E. (1995). The stakeholder theory of the corporation: Concepts, evidence and implications. Academy of Management Review, 20(1), 65-91.

Fama, E. F. (1970). Efficient Capital Markets: A Review of Theory and Empirical Work. Journal of Finance, 25, 383-417.

Fama, E. F. (1976). Foundations of Finance: Portfolio Decisions and Security Prices. New York: Basic.

Flammer, C. (2015). Does corporate social responsibility lead to superior financial performance? A regression discontinuity approach. Management Science, 61, 2549-2568.

Freeman, R. E. (1984). Strategic Management: A stakeholder approach. Boston, MA: Pitman.

Friedman, A. D. (2009). Statistical Models: Theory and Practice. New York: Cambridge University Press.

Gangi, F. (2011). Analisi degli Investimenti Aziendali. Milano: Egea.

Gelman, A., \& Hill, J. (2007). Data Analysis Using Regression and Multilevel / Hierarchical Models. New York: Cambridge University Press.

Godfrey, P. C. A., Merrill, C., \& Hansen, J. M. (2009). The relationship between corporate social responsibility and shareholder value: An empirical test of the risk management hypothesis. Strategic Management Journal, 425-445.

Green, W. H. (2000). Econometric Analysis (4th ed.). Upper Saddle River: Prentice Hall Inc

Griffin, J. J., \& Mahon J. F. (1997). The Corporate Social Performance and Corporate Financial Performance Debate: Twenty-Five Years of Incomparable Research. Business and Society, 36(1).

Hannan, M. T., \& Freeman, J. (1993). Ecologia Organizzativa. Milano: Etas.

Heinze, D. C. (1976). Financial correlates of a social involvement measure. Akron Business and Economic Review, 7(1), 48-51.

Hunter, J. E., \& Schmidt, F. L. (2004). Methods of meta-analysis: Correcting error and bias in research findings. London, UK: Sage.

Ingram, R. W. (1978). An investigation of the information content of (certain) social responsibility disclosure. Journal of Accounting Research, 16, 270-285.

Lankoski, L. (2008). Corporate responsibility activities and economic performance: a theory of why and how they are connected. Bus Strategy Environ, 17, 536-547.

Lawrence, S. et al. (2001). Persistence of Web References in Scientific Research. Computer, 34, 26-31. 
Margolis, J. D., \& Walsh, J. P. (2003). Misery loves companies: Rethinking social initiatives by business. Administrative Science Quarterly, 48(2).

McWilliams, A., \& Siegel, D. (2000). Corporate Social Responsibility and financial performance: correlation or misspecification?. Strategic Management Journal, 21(5).

Michelson, G., Wailes, N., Van Der Laan, S., \& Frost, G. (2004). Ethical Investment Processes and Outcomes. Journal of Business Ethics, 52(1), 1-10.

Moskowitz, M. (1972). Choosing socially responsible stocks. Business and Society Review, 1, 71-75.

Moskowitz, M. (1975). Profiles in corporate responsibility. Business and Society Review, 13, 29-42.

Nollet, J., Filis, G., \& Mitrokostas, E. (2016). Corporate social responsibility and firm performance: a non-linear and disaggregated approach. Econ Model, 52, 400-407.

Orlitzky, M., Schmidt, F. L., \& Rynes, S. L. (2003). Corporate, social and financial performance: A meta-analysis. Organization Studies, 24(3).

Patten, D. M. (1991). Exposure, legitimacy and social disclosure. Journal of Accounting and Public Policy, 10(4).

Post, J. E., Preston, L. E., \& Sachs, S. (2002). Managing the extent enterprise: the new stakeholder view. California Management Review, 45(1), 5-28.

Preston, L. E. (1978). Analysing Corporate Social Performance: Methods and results. Journal of Contemporary Business, 7(1), 135-149.

Preston, L. E., \& O’Bannon, D. P. (1997). The corporate social-financial performance relationship: A typology and analysis. Business \& Society, 36, 419-429.

Robinson, M., Kleffner, A., \& Bartels, S. (2011). Signalling sustainability leadership: empirical evidence of the value of DJSI membership. J Bus Ethics, 10, 493-505.

Scholtens, B. (2008a). Corporate social responsibility and the international banking industry. J Bus Ethics, 86, 159-175.

Schuler, D. A., \& Cording, M. (2006). A corporate social performance-corporate financial performance behavioral model for consumers. Acad Manag Rev, 31, 540-558.

Sciarelli, M. (2012). Corporate Social Performance. Il valore allargato nella prospettiva degli stakeholder, Lavis: Cedam.

Sciarelli, S. (2001). Economia e Gestione delle Imprese (3rd ed.). Padova: Cedam.

Sen, A. (2002). Etica ed Economia. Laterza.

Sen, A. S., Bhattacharya, C. B., \& Korshun, D. (2006). The role of corporate social responsibility in strengthening multiple stakeholder relationships: a field experiment. Journal of the Academy of Marketing Science, 158-166. 


\section{Ml Macrothink}

International Journal of Accounting and Financial Reporting ISSN 2162-3082

Signori, S. (2006). Gli investimenti etici: implicazioni aziendali. Milano: Giuffré.

Smith, J. (1999). One of Volvo's core values. Retrieved July 7, 2017, from http://www.volvo.com/environment/index.htm

Spicer, B. H. (1978). Investors, corporate social performance and information disclosure: An empirical study. The Accounting Review, 53(1), 94-111.

Strunk, W. Jr., \& White, E. B. (1979). The elements of style (3rd ed., Chapter 4). New York: Macmillan.

Sturdivant, F. D., \& Ginter, J. L. (1977). Corporate social responsiveness: management attitudes and economic performance. California Management Review, 19(3), 30-39.

Tomasi, F., \& Russo, A. (2012). Il Rating Etico: un'analisi Empirica del Modello Standard Ethics. Standard Ethics Research Office, London.

Van der Geer, J., Hanraads, J. A. J., \& Lupton R. A. (2000). The art of writing a scientific article. Journal of Scientific Communications, 163, 51-59.

Vance, S. C. (1975). Are socially responsible corporations good investment risks?. Management Review, 64(8).

Wang, Q., Dou, J., \& Jia, S. (2015). A meta-analytic review of corporate social responsibility and corporate financial performance: the moderating effect of contextual factors. Bus Soc.

Wright, P., \& Ferris, S. P. (1998). Agency conflict and corporate strategy: The effect of disinvestment on corporate value. Strategic Management Journal, 18(1). 


\section{Ml Macrothink}

International Journal of Accounting and Financial Reporting

ISSN 2162-3082

2018, Vol. 8, No. 4

\section{Appendix}

Appendix 1. The sample

\begin{tabular}{|c|c|c|c|c|c|c|c|c|}
\hline Company & 2013 & 2012 & 2011 & 2010 & 2009 & 2008 & 2007 & Industry Group \\
\hline ATLANTIA & $\mathrm{E}$ & $\mathrm{E}$ & $\mathrm{E}$ & $\mathrm{E}$ & E- & E- & $\mathrm{E}-$ & Industrial \\
\hline AUTOGRILL & $\mathrm{E}$ & $\mathrm{E}$ & E & $\mathrm{E}$ & $\mathrm{E}$ & $\mathrm{E}$ & $\mathrm{E}$ & Industrial \\
\hline BANCA MPS & $\mathrm{EE}-$ & $\mathrm{EE}-$ & EE- & $\mathrm{EE}-\mathrm{P}$ & EE- & EE- & $\mathrm{EE}-$ & Financial \\
\hline BANCA POPOLARE EMILIA ROMAGNA & $\mathrm{EE}$ & $\mathrm{EE}$ & & & & & & Financial \\
\hline BANCA POPOLARE MILANO & PEND & SOSP & $\mathrm{EE}$ & $\mathrm{EE}$ & $\mathrm{EE}$ & $\mathrm{EE}$ & $\mathrm{EE}$ & Financial \\
\hline CAMPARI & $\mathrm{EE}-$ & $\mathrm{EE}-$ & EE- & $\mathrm{EE}-$ & & & & Industrial \\
\hline DIASORIN & $\mathrm{EE}-$ & $\mathrm{E}+$ & $\mathrm{E}+$ & & & & & Industrial \\
\hline ENEL & $\mathrm{EE}+$ & $\mathrm{EE}+$ & $\mathrm{EE}$ & $\mathrm{EE}$ & $\mathrm{EE}$ & $\mathrm{EE}$ & $\mathrm{EE}$ & Resources \\
\hline ENEL GREEN POWER & $\mathrm{EE}$ & $\mathrm{EE}$ & EE- & & & & & Resources \\
\hline ENI & EEE- & EEE- & $\mathrm{EE}+$ & $\mathrm{EE}+$ & $\mathrm{EE}+$ & $\mathrm{EE}+$ & $\mathrm{EE}+$ & Resources \\
\hline EXOR & $\mathrm{E}$ & E & E & $\mathrm{E}$ & & & & Financial \\
\hline INTESA SANPAOLO & EE- & $\mathrm{EE}-$ & $\mathrm{E}+$ & $\mathrm{E}+$ & $\mathrm{E}$ & $\mathrm{E}$ & $\mathrm{E}$ & Financial \\
\hline LUXOTTICA GROUP & EE- & EE- & EE- & EE- & EE- & EE- & EE- & Industrial \\
\hline MEDIASET & $\mathrm{E}-$ & $\mathrm{E}-$ & $\mathrm{E}-$ & $\mathrm{E}$ & $\mathrm{E}-$ & E- & $\mathrm{E}-$ & Services \\
\hline MEDIOBANCA & $\mathrm{E}+$ & $E+$ & $E$ & $E$ & $\mathrm{E}$ & $\mathrm{E}$ & $\mathrm{E}$ & Financial \\
\hline MEDIOLANUM & E- & E- & $\mathrm{E}-\mathrm{H}$ & E- & E- & E- & $\mathrm{E}-$ & Financial \\
\hline PARMALAT & PEND & $\mathrm{E}$ & $\mathrm{E}+$ & EEE- & $\mathrm{EE}+$ & $\mathrm{EE}+$ & $\mathrm{EE}+$ & Industrial \\
\hline PIRELLI\&C & $E+$ & $\mathrm{E}+$ & $\mathrm{E}+$ & $\mathrm{E}+$ & $E+$ & $\mathrm{E}+$ & $\mathrm{E}+$ & Industrial \\
\hline PRYSMIAN & $\mathrm{EE}$ & EE- & $E+$ & $E+$ & SOSP & SOSP & SOSP & Industrial \\
\hline SAIPEM & $\mathrm{EE}+$ & $\mathrm{EE}+$ & $\mathrm{EE}+$ & $\mathrm{EE}+$ & $\mathrm{EE}+$ & $\mathrm{EE}+$ & $\mathrm{EE}+$ & Industrial \\
\hline SALVATORE FERRAGAMO & $\mathrm{E}$ & E & & & & & & Industrial \\
\hline SNAM & $\mathrm{EE}-$ & EE- & EE- & $\mathrm{EE}-$ & EE & $\mathrm{EE}$ & $\mathrm{EE}$ & Resources \\
\hline STMICROELECTRONICS & $\mathrm{EE}$ & $\mathrm{EE}$ & $\mathrm{EE}$ & $\mathrm{EE}$ & $\mathrm{EE}$ & $\mathrm{EE}$ & $\mathrm{EE}$ & Industrial \\
\hline TELECOM ITALIA & EE- & $\mathrm{EE}-$ & EE- & EE- & EE- & $\mathrm{E}$ & $\mathrm{E}$ & Services \\
\hline
\end{tabular}

\section{Notes}

Note 1. The authors would like to thank Prof. Luigi D'Ambra (Federico II University) for his scientific advice regarding the data analysis implemented for the study.

Note 2. Consulting and auditing firm whose survey is available at the following link:

http://www.grantthornton.global/en/press/press-releases-2014/Sustainability-reporting/.

Note 3. This definition is available on the Borsa Italiana website page: http://www.borsaitaliana.it/borsa/indici/indici-in-continua/dettaglio.html?indexCode=FTSEM IB.

Note 4. Available respectively at the following web portals: http://www.borsaitaliana.it/borsa/azioni/ftse-mib/lista.html, http://www.morningstar.com/, https://it.finance.yahoo.com/.

\section{Copyright Disclaimer}

Copyright for this article is retained by the author(s), with first publication rights granted to the journal.

This is an open-access article distributed under the terms and conditions of the Creative Commons Attribution license (http://creativecommons.org/licenses/by/4.0/) 